\title{
Hubungan antara intravesical prostatic protrution, International prostatic symptom score, dan uroflowmetry pada kasus benign prostatic hyperplasia di RSUP Prof. Dr. R. D. Kandou Manado
}

\author{
${ }^{1}$ Jefri, ${ }^{2}$ Alwin Monoarfa, ${ }^{3}$ Ainun Aschorijantot, ${ }^{2}$ Richard Monoarfa, ${ }^{4}$ Vonny Tubagus
}

\author{
${ }^{1}$ Program Studi Ilmu Bedah Fakultas Kedokteran Universitas Sam Ratulangi Manado \\ ${ }^{2}$ Bagian Ilmu Bedah Fakultas Kedokteran Universitas Sam Ratulangi Manado \\ ${ }^{3}$ KSM Ilmu Bedah RSUP Prof. Dr. R. D. Kandou Manado \\ ${ }^{4}$ Bagian Radiologi Fakultas Kedokteran Universitas Sam Ratulangi Manado \\ Email: jefri.tjia85@gmail.com
}

\begin{abstract}
Benign prostatic hyperplasia $(\mathrm{BPH})$ is a prostatic gland enlargement due to hyperplasia of its glandular tissue and stroma which can cause low urinary tract symptoms (LUTS). This prostatic gland enlargement could be evaluated by using intravesical prostatic protrution (IPP) with transabdominal ultrasound. This study was aimed to analyze the relationship among IPP, LUTS (evaluated by using International prostate symptom score/IPSS), and uroflowmetry in BPH patients at Prof. Dr. R. D. Kandou Hospital Manado. This was an observational analytical correlation study with a cross sectional design. Subjects were BPH patients at Prof. Dr. R. D. Kandou Hospital from August 2016 to December 2016. IPP with transabdominal ultrasound, IPSS, and uroflowmetry were evaluated in all subjects. Data were anlayzed by using Spearman correlation test. The results showed that there were no significant relationships between IPP and uroflowmetry $(\mathrm{r}=-0.243 ; P=0.165)$; IPP and IPSS $(\mathrm{r}=0.173 ; P=0.246)$; and uroflowmetry and IPSS $(\mathrm{r}=0.091 ; P=0.360)$. Conclusion: There were no significant relationships among IPP with transabdominal ultrasound, IPSS. and uroflowmetry.
\end{abstract}

Keywords: IPP, LUTS, uroflowmetry

\begin{abstract}
Abstrak: Benign prostatic hyperplasia (BPH) adalah pembesaran kelenjar prostat yang disebabkan oleh hiperplasia jaringan kelenjar dan komponen stroma yang dapat menyebabkan low urinary tract symptoms (LUTS). Pembesaran kelenjar prostat dapat dievaluasi dengan intravesical prostatic protrution (IPP) menggunakan transabdominal ultrasonografi. Penelitian ini bertujuan untuk menganalisis hubungan antara IPP, LUTS (yang dinilai dengan International prostate symptom score; IPSS) dan uroflowmetry pada pasien BPH di RSUP Prof. Dr. R. D. Kandou Manado. Jenis penelitian ialah korelasi analitik observasional dengan studi potong lintang. Subyek penelitian ialah pasien BPH di RSUP Prof. Dr. R. D. Kandou Manado sejak bulan Agustus 2016 hingga Desember 2016. Pada semua subyek penelitian dilakukan evaluasi IPP menggunakan transabdominal ultrasonografi, IPSS, dan uroflowmetry. Data dianalisis dengan uji korelasi Spearman. Hasil analisis hubungan antara IPP dan uroflowmetry menunjukkan tidak terdapat hubungan bermakna antara keduanya $(\mathrm{r}=-0,243 ; P$ $=0,165)$. Hasil analisis hubungan antara IPP dan IPSS menunjukkan tidak terdapat hubungan bermakna antara keduanya $(\mathrm{r}=0,173 ; P=0,246)$. Hasil analisis terhadap hubungan antara uroflowmetry dan IPSS menunjukkan tidak terdapat hubungan bermakna antara keduanya $(\mathrm{r}=$ 0,091; $P=0,360)$. Simpulan: Tidak terdapat hubungan bermakna antara hasil evaluasi IPP secara transabdominal ultrasonografi, IPSS, dan uroflowmetry.
\end{abstract}

Kata kunci: IPP, LUTS, uroflowmetry 
Benign prostatic hyperplasia (BPH) adalah pembesaran nodular kelenjar yang disebabkan oleh hiperplasia dari jaringan kelenjar prostat dan komponen stroma. ${ }^{1}$ Benign prostatic hyperplasia merupakan salah satu tumor jinak yang paling sering terjadi pada laki-laki dan sebagai penyebab tersering terjadinya bladder outlet obstruction (BOO) pada laki-laki di atas usia 50 tahun. $^{2}$ Pembesaran kelenjar ini biasanya terjadi sejak usia 40 tahun. Prevalensinya meningkat sampai 50\% pada usia 50 tahun dan bisa mencapai $90 \%$ pada usia di atas 85 tahun.

Pada BPH, hiperplasia terjadi di zona transisional yang disebabkan oleh karena pertambahan jumlah sel. Pada pemeriksaan histologik, pembesaran kelenjar prostat terdiri dari komponen stromal dan epitel. Perbedaan gambaran histologik pada pasien $\mathrm{BPH}$ penting dalam menentukan penatalaksanaan. Pemberian alfa bloker memberikan respon yang sangat baik pada pasien $\mathrm{BPH}$ dengan komponen otot polos yang dominan, sebaliknya $5 \alpha$-reduktase inhibitor lebih efektif diberikan pada pasien BPH dengan sel epitel yang dominan. Sekitar $50 \%$ laki-laki yang mengalami BPH mempunyai keluhan lower urinary tract symptom (LUTS). Derajat LUTS dapat dihitung berdasarkan International prostate symptom score (IPSS). ${ }^{3}$

Perubahan morfologik dan fungsional yang terjadi pada pasien BPH bisa disebabkan karena peningkatan volume prostat serta peningkatan aktivitas reseptor alfa adrenergik pada stroma kelenjar prostat, kapsul kelenjar prostat, dan bladder neck. Benign prostatic hyperplasia dapat menyebabkan gejala LUTS, dan merupakan salah satu faktor penyebab retensi urin pada pembesaran prostat yang dapat dilihat dari intravesical prostatic protrution (IPP) yaitu penonjolan prostat ke dalam buli-buli. ${ }^{4}$ Intravesical prostatic protrution menyebabkan obstruksi pada buli-buli melalui mekanisme valve ball, yaitu bagian lateral dan medial dari kelenjar prostat menyebabkan buli-buli tidak dapat membuka sempurna saat berkemih. Pengukuran IPP tidak hanya memberikan informasi tentang terjadinya obstruksi buli-buli, tetapi juga mengenai grading yaitu grade $\mathrm{I}(<5 \mathrm{~mm})$, grade II $(5-10 \mathrm{~mm})$, dan grade III $(>10$ $\mathrm{mm})$. Pengukuran IPP dilakukan berdasarkan transabdominal ultrasonografi (USG) yang merupakan pemeriksaan relatif mudah dan non-invasif. ${ }^{4,5}$ Terdapatnya IPP mempunyai hubungan erat dengan terjadinya LUTS pasien BPH. ${ }^{5}$

Uroflowmetry ialah salah satu metode non-invasif yang dapat membantu seorang ahli urologi dalam mendiagnosis BOO. Pemeriksaan ini dapat memberikan gambaran pancaran buang air kecil pasien dengan BOO tetapi tidak dapat menjelaskan penyebabnya. ${ }^{6,7}$

Penelitian ini bertujuan untuk mengetahui hubungan antara IPP, IPSS, dan uroflowmetry pada kasus BPH di RSUP Prof. Dr. R. D. Kandou Manado

\section{METODE PENELITIAN}

Jenis penelitian ini ialah korelasi analitik observasional dengan studi potong lintang untuk menganalisis hubungan antara IPP, IPSS (penilaian LUTS), dan uroflowmetry pada pasien BPH di RSUP Prof. Dr. R. D. Kandou Manado. Subyek penelitian ialah pasien BPH di RSUP Prof. Dr. R. D. Kandou Manado sejak bulan Agustus 2016 hingga Desember 2016.

Pada semua subyek penelitian dilakukan pengukuran IPSS, IPP berdasarkan transabdominal ultrasonografi, dan uroflowmetry. Hubungan antar variabel diuji dengan koefisien korelasi Spearman

\section{HASIL PENELITIAN}

Dari 18 pasien $\mathrm{BPH}$ yang dilibatkan dalam penelitian ini sejak bulan Agustus 2016 hingga Desember 2016, didapatkan kelompok usia 50-59 tahun sebanyak 4 orang $(22,3 \%)$, kelompok usia 60-69 tahun sebanyak 8 orang $(44,4 \%)$, dan kelompok usia 70-79 tahun sebanyak 6 orang $(33,3 \%)$ (Gambar 1). Usia minimum ialah 53 tahun dan usia maksimum ialah 75 tahun (rerata 64,67 tahun) (Tabel 1). Seluruh pasien dalam penelitian ini, memperlihatkan IPP grade I yaitu $<5 \mathrm{~mm}$; tidak ada satupun pasien dengan grade II atau III (Gambar 2). 


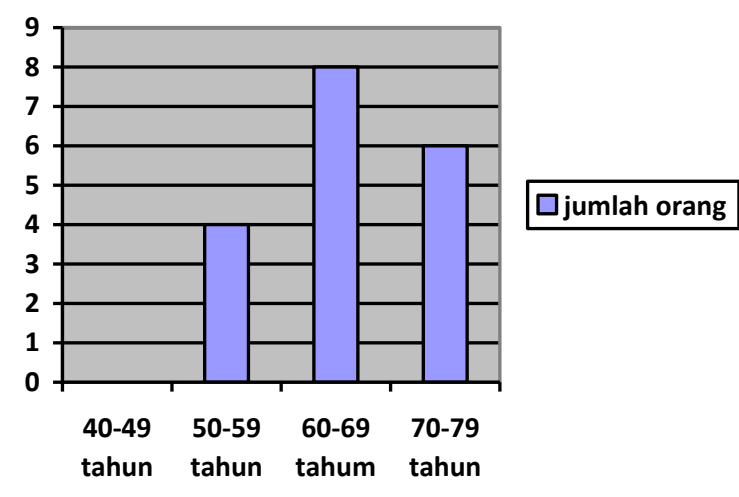

Gambar 1. Distribusi kelompok usia subyek penelitian
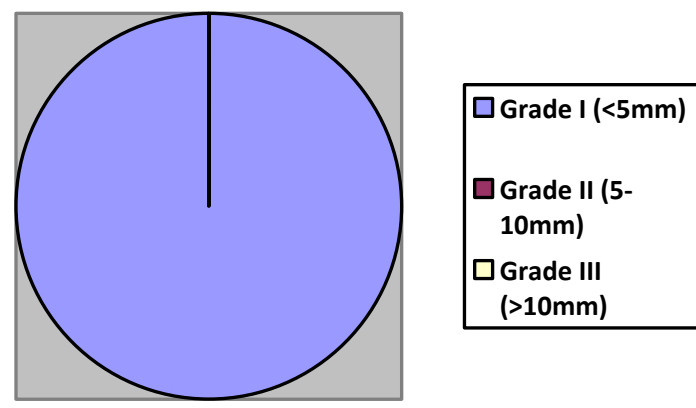

Gambar 2. Distribusi hasil evaluasi IPP dari subyek penelitian
Berdasarkan distribusi hasil pengukuran IPP pada 18 pasien didapatkan nilai minimum sebesar $0.28 \mathrm{~mm}$ dan nilai maksimum sebesar 3,72 mm dengan rerata sebesar 1,0933 (Tabel 2). Pada distribusi penilaian IPSS, ditemukan nilai terbesar 30 dan nilai terkecil 6 dengan rerata 15,06 (Tabel 3). Hasil pengukuran pancaran air kencing yang dilakukan dengan menggunakan uroflowmetry, mendapatkan pancaran terkuat 11 detik dan pancaran terlemah 0,3 detik dengan rerata 5,1222 (Tabel 4).

Hasil analisis koefisien korelasi Spearman terhadap hubungan antara IPP dan uroflowmetry mendapatkan nilai $\mathrm{r}=$ 0,243 dan $P=0,165$ yang menunjukkan tidak terdapat hubungan bermakna antara keduanya. Hasil analisis koefisien korelasi Spearman terhadap hubungan antara IPP dan IPSS mendapatkan nilai $r=0,173$ dan $P=0,246$ yang menunjukkan tidak terdapat hubungan bermakna antara keduanya. Hasil analisis koefisien korelasi Spearman terhadap hubungan antara uroflowmetry dan IPSS mendapatkan nilai $r=0,091$ dan $P=0,360$ yang menunjukkan tidak terdapat hubungan bermakna antara keduanya.

Tabel 1. Distribusi pasien berdasarkan usia

\begin{tabular}{cccccc}
\hline & N & Min & Maks & Rerata & Simpang baku \\
\hline Usia & 18 & 53 & 75 & 64,67 & 6,851 \\
\hline
\end{tabular}

Tabel 2. Distribusi pasien berdasarkan hasil evaluasi IPP

\begin{tabular}{cccccc}
\hline & $\mathbf{N}$ & Min & Maks & Rerata & Simpang baku \\
\hline IPP & 18 & 0,28 & 3,72 & 1,0933 & 0,78910 \\
\hline
\end{tabular}

Tabel 3. Distribusi pasien berdasarkan penilaian IPSS

\begin{tabular}{cccccc}
\hline & N & Min & Maks & Rerata & Simpang baku \\
\hline IPSS & 18 & 6 & 30 & 15,06 & 8,098 \\
\hline
\end{tabular}

Tabel 4. Distribusi hasil pengukuran pancaran air kencing dengan uroflowmetry

\begin{tabular}{lccccc}
\hline & N & Min & Maks & Rerata & Simpang baku \\
\hline Uroflowmetry & 18 & 0,3 & 11 & 5,1222 & 3,73813 \\
\hline
\end{tabular}




\section{BAHASAN}

Benign prostatic hyperplasia merupakan jenis tumor jinak yang paling sering ditemukan pada laki-laki. Usia merupakan kondisi yang sangat berkaitan dengan $\mathrm{BPH}$. Kejadian BPH akan semakin meningkat seiring dengan bertambahnya usia. ${ }^{8-10}$ Sebanyak 18 pasien BPH yang terlibat dalam penelitian ini menunjukkan bahwa rerata usia pasien ialah 64,67 tahun dengan rentang usia 53-75 tahun. Hal ini sejalan dengan penelitian Ikuerowo et al. ${ }^{11}$ di Nigeria yang mendapatkan rerata usia pasien BPH di klinik 64,8 tahun dengan rentang usia 46-84 tahun dan penelitian oleh Glina et al. ${ }^{12}$ di Brazil dengan rerata usia pasien BPH di klinik ialah 61,7 tahun dengan rentang usia 45-82 tahun. Hasil penelitian ini tidak jauh berbeda dengan penelitian oleh Shao et al. ${ }^{13}$ di China yang mendapatkan rerata usia pasien BPH ialah 67,90 tahun dan penelitian oleh Minana et al. ${ }^{14}$ di Spanyol yang mendapatkan rerata usia pasien BPH di klinik 65,7 tahun.

Hasil penelitian dari Ozayar et al. ${ }^{15}$ mendapatkan rerata usia pasien $\mathrm{BPH}$ ialah 66,5 tahun dengan rentang usia 50-89 tahun dan yang terbanyak pada kelompok usia 70-79 tahun sebesar 38\% diikuti oleh kelompok usia 60-69 tahun sebesar 35\%. Pada pasien BPH rawat jalan di Klinik Urologi RSUP Prof. Dr. R. D. Kandou Manado ditemukan paling banyak ialah kelompok usia 60-69 tahun $(44,4 \%)$ diikuti oleh kelompok usia 70-79 tahun (33,3\%). Hal yang menyebabkan jumlah pasien kelompok usia 70-79 tahun lebih sedikit dibandingkan kelompok usia 60-69 tahun pada penelitian ini mungkin dikarenakan tidak banyak orang yang mencapai usia di atas 69 tahun dan juga jumlah kunjungan ke rumah sakit untuk pasien kelompok usia 70-79 tahun memang lebih sedikit dibandingkan kelompok usia 60-69 tahun.

Pada penelitian ini digunakan pemeriksaan transabdominal ultrasonografi yang merupakan salah satu pemeriksaan penunjang dalam menentukan IPP. Walaupun pemeriksaan transabdominal USG bersifat subjektif karena sangat bergantung pada dokter operatornya, namun pemeriksaan ini menjadi pemeriksaan standar pada pembesaran kelenjar prostat karena pemeriksaan ini bersifat tidak invasif dan relatif murah serta tidak memiliki bahaya radiasi.

Pada penelitian ini, hasil evaluasi IPP pada seluruh pasien didapatkan berukuran $<5 \mathrm{~mm}$ dan tidak didapatkan hubungan bermakna antara IPP dan IPSS. Hal ini tidak sejalan dengan penelitian yang dilakukan oleh Tjahjodjati dan Jumadi $^{5}$ di RS Hasan Sadikin Bandung pada tahun 2014 yang mendapatkan hubungan bermakna antara IPP dan IPSS. Perbedaan ini mungkin disebabkan karena Tjahjodjati dan Jumadi mengukur IPP secara transrektal; kelebihan cara tersebut ialah dapat menilai pembesaran prostat ke arah lateral. Selain itu, jumlah subyek yang diteliti oleh Tjahjodjati jauh lebih banyak daripada jumlah subyek penelitian ini.

Pada penelitian ini tidak terdapat hubungan bermakna antara IPP dan IPSS. Hal ini dapat disebabkan karena LUTS bersifat multifaktorial, adanya abnormalitas motorik dan sensorik dari otot detrusor, gangguan kontraktilitas detrusor, disfungsi uretra, usia, kebiasaan dan gaya hidup; kesemuanya ini dapat memengaruhi skoring IPSS. Benign prostatic hyperplasia hanya merupakan salah satu dari sekian banyak faktor lainnya yang dapat menyebabkan gejala LUTS. ${ }^{16}$

Hasil penelitian ini menyatakan tidak terdapat hubungan bermakna antara IPP dan uroflowmetry yang sejalan dengan penelitian yang dilakukan oleh Tjahjodjati dan Jumadi ${ }^{5}$ di RS Hasan Sadikin Bandung.

Pada penelitian ini juga tidak didapatkan hubungan bermakna antara IPSS dan uroflowmetry. Hal ini sesuai dengan penelitian sebelumnya oleh Girman et al. $^{17}$ dan Barry et al. ${ }^{18}$ yang tidak mendapatkan hubungan bermakna secara statistik antara maximum flow rate $\left(\mathrm{Q}_{\max }\right)$, prostate volume (PV) dan skor gejala. Nitti et al. ${ }^{19}$ juga gagal menemukan adanya hubungan klinis atau statistik antara tingkat keparahan BOO berdasarkan pressure-flow dan LUTS. Pada laki-laki, LUTS bisa berhubungan dengan BOO, tetapi baik 
storage maupun voiding symptoms bukan merupakan petanda diagnostik dari obstruksi urodinamik.

Walaupun IPSS tidak spesifik untuk suatu penyakit, tetapi sampai saat ini IPSS masih merupakan alat bantu untuk menilai tingkat keparahan LUTS yang mengarah ke BOO, dan untuk menilai outcome terapeutik.

\section{SIMPULAN}

Dari hasil penelitian terhadap pasien benign prostatic hyperplasia di RSUP Prof. Dr. R. D. Kandou Manado dapat disimpulkan bahwa tidak terdapat hubungan bermakna antara hasil evaluasi intravesical prostatic protrution menggunakan transabdominal ultrasonografi, International prostate symptom score, dan uroflowmetry.

\section{DAFTAR PUSTAKA}

1. Tanagho EA, McAninch JW. Smith's General Urology (17th ed). New York: McGraw-Hill Companies, Inc, 2008.

2. Lee WS, Cho MJ, Kang YJ, Yoo KT. Clinical and urodinamic significance of morphological differences in intravesical prostatic protrution. Korean J Urol. 2010;51:694-9

3. Basawaraj NG, Dasan AT, Patil SS. Correlation of sonographic prostate volume with international prostate symptom score in South Indian men. Int J Res Med Sci. 2015;3(11):312630.

4. Aganovic D, Prcic A, Hadziosmanovic O, Hasanbegovic $M$. Does the combination of intravesical prostatic protrution and bladder outlet obstruction number increase test accuracy according to benign prostatic obstruction at the individual level? Acta Inform Med. 2012;20(3):160-6.

5. Tjahjodjati, Jumadi S. Relationship between prostate urethral angle, intravesical prostatic protrution, international prostatic symptom score, and uroflowmetry in benign prostatic hyperplasia patients. IJIHS.2015;3(2):50-4.

6. Zambon PJ, Batezini SSN, Junior KJA,
Conceicao ODR, Carvalho MAJ, Almeida GF. Uroflowmetry in a large population of Brazilian men submitted to a health check up program and its correlation with IPSS and prostate size. Int Braz $\mathrm{J}$ Urol. 2013;39:841-6.

7. Reynard J, Brewster S, Biers S. Bladder outlet obstruction (Chapter 4). In: Oxford Handbook of Urology (1st ed). Oxford: Oxford University Press, 2006.

8. Roehrborn CG, McConnell JD. Benign prostatic hyperplasia: Etiology, pathophysiology, epidemiology, and natural history (Chapter 86). In: Wein AJ, Kavoussi LR, Novick AC. Campbell-Walsh Urology (9th ed). USA: Saunders, an imprint of Elsevier, 2007.

9. Olumi AF, Richie JP. Urologic surgery: benign prostatic hyperplasia (Chapter 77). In: Townsend CM, Beauchamp RD, Evers BM, Mattox KL. Sabiston Textbook of Surgery. The Biological Basis of Modern Surgical Practice (18th ed). USA: Saunders, an imprint of Elsevier, 2008.

10. Fibbi B, Penna G, Morelli A, Adorini L, Maggi M. Chronic inflammation in the pathogenesis of benign prostatic hyperplasia. Int J Androl. 2010; 33:475-88.

11. Ikuerowo SO, Akindiji YO, Akinlusi FM, Esho JO. Association between erectile dysfunction and lower urinary tract symptoms due to benign prostatic hyperplasia in Nigerian men. Urol Int. 2008;80(3):296-9.

12. Glina S, Santana AW, Azank F, Mello LF, Moreira ED. Lower urinary tract symptoms and erectile dysfunction are highly prevalent in aging men. BJU International. 2006;97(4):763-5.

13. Shao Q, Song J, Guo YW, Lu WC, Du LD. Evaluation of sexual function in men with symptomatic benign prostatic hyperplasia. Zhonghua Nan Ke Xue. 2005;11(7):505-7.

14. Minana B, Rodriguez-Antolin A, Proeto M, Pedrosa E. Severity profiles in patients diagnosed of benign prostatic hyperplasia in Spain. Actas Urol Esp. 2013.

Doi: 10.1016/j.acuro.2013.03.003. 
15. Ozayar A, Zumrutbas AE, Yaman O. The relationship between lower urinary tract symptoms (LUTS), diagnostic indicators of benign prostatic hyperplasia (BPH), and erectile dysfunction in patients with moderate to severely symptomatic BPH. Int Urol Nephrol. 2008;40(4):933-9.

16. Chapple C, McVarry K, Roehrborn C, Abrams P. Male lower urinary tract symptoms. An International Consultation on Male LUTS. Fukuoka (Japan), 2012.

17. Girman CJ, Panser LA, Chute CG.
Natural history of protatism: urinary flow rates in a community-based stdutdy. J Urol. 1993;150:887-92.

18. Barry MJ, Cockett ATK, Holtgrewe HL, McConnell JD, Sihelnik SA, Winfield HN. Relationship of symptoms of prostatism to commonly used physiological and anatomical measures of the severity of benign prostatic hyperplasia. J Urol. 1993;150:351-8.

19. Nitti VW. Pressure flow urodynamic studies: The gold standard for diagnosing bladder outlet obstruction. Rev Urol. 2005;7(Suppl 6):S14-S21. 